\title{
Landscape Factors that Influence European Starling (Sturnus vulgaris) Nest Box Occupancy at NASA Plum Brook Station (PBS), Erie County, Ohio, USA
}

MORGAN B. PFEIFFER', U.S. Department of Agriculture, Animal and Plant Health Inspection Service, Wild life Services, National Wildlife Research Center, Ohio Field Station, Sandusky, OH, USA and School of Natural Resource Management, Nelson Mandela University, George, South Africa; THOMAS W. SEAMANS, BRUCE N. BUCKINGHAM, and BRADLEY F. BLACKWELL, U.S. Department of Agriculture, Animal and Plant Health Inspection Service, Wildlife Services, National Wildlife Research Center, Ohio Field Station, Sandusky, OH, USA.

ABSTRACT. During the last decade at NASA Plum Brook Station (PBS), Erie County, Ohio, United States, there has been a nearly $50 \%$ decrease in European Starling (Sturnus vulgaris) occupancy (nests with $\geq 1 \mathrm{egg}$ ) of nest boxes designed to be used by starlings. Increased availability of natural cavities, from invertebrate pests, might have altered nest box occupation rates. It was hypothesized that starling nest box occupation rates would be a function of an index of potentially suitable tree cavities for nesting starlings, the semi-colonial nature of breeding starlings, and access to foraging areas (e.g., mowed lawns near buildings). Specifically, it was predicted that starling occupancy of nest boxes would correlate positively with a low density of potentially suitable tree cavities (calculated from a constructed index based on characteristics preferred by nesting starlings), and proximity of other starling occupied nest boxes and anthropogenic structures or mowed lawns. The objective was to quantify landscape factors around nest boxes with known starling occupation rates. Potentially suitable tree cavities were readily available near nest boxes. However, starling nest box occupation was instead a function of proximity to buildings, a factor associated with additional nesting sites and preferred foraging areas (mowed lawns). Nesting starlings in this study were influenced by anthropogenic structures and associated resources.

\section{INTRODUCTION}

Cavity nesting birds can be separated into 3 guilds: (1) primary excavators, (2) weak cavity excavators, and (3) secondary cavity nesters (Martin et al. 2004). Nest site selection by a secondary cavity nester, a species which cannot excavate their own cavities, rely on primary and weak excavators (or naturally occurring cavities) for nesting (Newton 1994; Aitken and Martin 2008). One secondary cavity nester, the European Starling (Sturnus vulgaris; hereinafter, starling), is one of the most globally successful birds, and competes for nest sites with primary and weak cavity excavators (Kessel 1957; Ingold 1994; Marzluff et al. 2001).

Originally from Europe and western Asia, the starling was introduced to the United States in the 1890s in New York City and, since, has expanded its distribution to include much of North America (Chapman 1925; Bent 1950; Kessel 1957; Linz et

${ }^{1}$ Address correspondence to Morgan B. Pfeiffer, U.S. Department of Agriculture, Animal and Plant Health Inspection Service, Wildlife Services, National Wildlife Research Center, Ohio Field Station, 6100 Columbus Avenue, Sandusky, OH 44870, USA. Email: Morgan.B.Pfeiffer@usda.gov al. 2017). Starlings have also been introduced into Australasia, the Pacific and Caribbean islands (Feare 1984), South America (Pérez 1988; Zufiaurre et al. 2016), and South Africa (Winterbottom and Liversidge 1954). The species is considered a general vertebrate pest in their introduced and native ranges (Feare 1984; Pimentel etal.2000; DeVault etal. 2011).

Part of the success of the starling stems from its behavioral innovation and ability to exploit novel nesting and foraging resources (Mennechez and Clergeau 2006). Starlings will nest in anthropogenic structures located near mowed areas (Feare 1984; Mennechez and Clergeau 2006) and share information socially, especially during the high energetic demand of the breeding season (Kessel 1957; Caccamise and Morrison 1986). Relative to plasticity in nest-site selection, starlings have also constructed nests inside engines and control surfaces

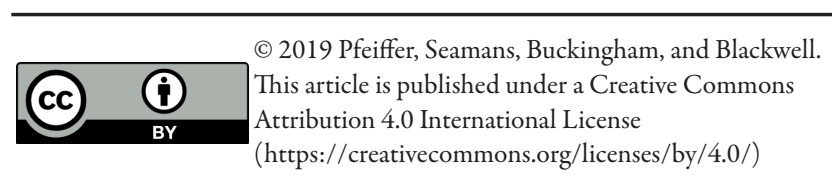


of aircraft that were inactive for only a few days, and introduced materials which could have resulted in a system malfunction and/or fire (Bridgman 1962; Jackson 2000). Further, the species is highly aggressive and persistent in nest-site selection; starlings have usurped cavities from numerous species including raptors (Bent 1950; Ingold 1989; Kerpez and Smith 1990; Ingold 1994; McClure et al. 2015). Starlings, therefore, can pose adverse effects on the fecundity of native avian species (Koenig 2003; Koenig et al. 2017).

In conservation applications, intending to reduce nest site competition by starlings, variations of "starling-proof" nest boxes have been successful (McGilvrey and Uhler 1971; Tyson et al. 2011; Campbell et al. 2012). However, nesting starlings are still a formidable problem because they nest in a variety of anthropogenic structures. In these instances, nesting deterrents (e.g., chemically-based predator cues) applied at potential nest sites hold more potential as a management tool (Blackwell et al. 2018).

Studies at the National Aeronautics and Space Administration (NASA) Plum Brook Station (PBS), Erie County, Ohio, United States-a site in northern Ohio where starling nesting deterrent methods have been tested for 30 years (Seamans et al. 2015) — report declining starling nest box occupancy (nests with $\geq 1 \mathrm{egg}$ ) rates from approximately 100\% to as low as $50 \%$, regardless of applied deterrents (Dolbeer et al. 1988; Belant et al. 1998; Seamans et al. 2015; Blackwell et al. 2018). As late as 2017, starlings occupied only $57 \%$ of available boxes at the site (Blackwell et al. 2018). Data from the North American Breeding Bird Survey (BBS; Pardieck et al. 2018) indicated a decrease in the number of starlings observed on BBS routes in Ohio since 1966; yet, 182 starlings were observed per route in the bird conservation region of the lower Great Lakes/St. Lawrence Plain in 2015, surpassing most other species. Seamans et al. (2015) and Blackwell et al. (2018), however, speculated that lower nest box occupation rates by starlings at a northern Ohio site were not attributable to a declining population, but rather the increased availability of tree cavities for nesting, particularly in response to tree damage from invertebrate pests.
Specifically, the forest structure in the midwestern United States, and Ohio particularly, has changed drastically since the 1980s, due in part to damage by the invasive emerald ash borer (Agrilus planipennis) which has created an abundance of white ash (Fraxinus americana) snags (ODNR 2019). Further, populations of certain woodpecker species (e.g., Red-bellied Woodpecker; Melanerpes carolinus) in ash borer-impacted areas have responded positively with the abundance of ash snags (Koenig et al. 2013). Red-bellied Woodpeckers, moreover, compete poorly with starlings for available cavities (Ingold 1994). Studies from the United States and Europe have also shown that starlings prefer freshly excavated or limb-break cavities, with no old nesting material (Ingold 1998; Mazgajski 2000; Mazgajski 2003), to nest boxes (Planck 1969). Tree cavities without nesting material from the prior year necessitate less effort for new nest preparation, which allows more energy to be expended on other activities (Mazgajski 2007). Finally, excavated and limb-break cavities can provide cavity concealment, whereas nest predators can learn to associate identical activity at nest boxes with prey (i.e., acquire a search image for potential prey locations; Feare 1984; Wesołowski 2017).

Givenits relativeabundancein Ohio, aggressiveness in nest-site selection, and use of multiple resources as potential nest sites, itwas hypothesized that nest box occupancy by starlings would be a function of not only the availability ofpotentially suitable tree cavities (Planck 1969; Mouton and Martin 2018), but also the semi-colonial nature of breeding starlings and access to foraging areas (e.g., mowed lawnsnear buildings). Specifically, it was predicted that starling occupancy of nest boxes would be (1) negatively correlated with higher total plot scores which assessed potentially suitable tree cavities within $100 \mathrm{~m}$ of nest boxes using a constructed index (Planck 1969; Peterson and Gauthier 1985; Carlson et al. 1998; Aitken and Martin 2004); (2) positively correlated with the increased proximity of other starling occupied nest boxes, based on the species' semi-colonial habits, which are thought to enhance foraging success through information exchange (Kessel 1957; Krause and Ruxton 2002); and (3) in proximity to buildings and their resources (Feare 1984). 


\section{Nest Box Placement}

\section{METHODS}

The study was conducted on the 2,200 ha NASA Plum Brook Station (PBS), Erie County, Ohio, United States (lat $41^{\circ} 22^{\prime} 19^{\prime \prime N}$, long 82 $40^{\prime} 49^{\prime \prime W}$ ). The habitats contained within PBS support a high level of biodiversity including 39\% canopy-dogwood (Cornus spp.), 15\% open woodlands, and $11 \%$ of mixed hardwood forests (Bowles and Arrighi 2004; Tyson et al. 2011). Nest boxes designed to encourage nesting by starlings have been on the property since 1984. Their purpose was to test nesting deterrent methods and products, many of which had no effect (Belant et al. 1998).

In 2011, approximately 50 wooden nest boxes $(28 \times 13 \times 17 \mathrm{~cm}$, with a $5.1 \mathrm{~cm}$ diameter entrance $)$ were attached to utility poles on PBS. The nest boxes were placed 2.5 to $3.0 \mathrm{~m}$ above the ground. These nest boxes were closed in 2015 and reopened in early 2017 after old nest material was removed. Additionally, 70 new wooden nest boxes were added to utility poles in early 2017 (Blackwell et al. 2018), which increased the total number of nest boxes to 120. It was assumed that age of the nest box did not influence occupation rates because of the short duration ( 2 years) between nest box placements. All utility poles with nest boxes were affixed with aluminum predator guards below the boxes, a feature common to previous research at the site (Seamans et al. 2015). During 2017, the nest boxes were used in an experimental design to investigate the efficacy of predator scent as a means to deter starlings from nesting (Blackwell et al. 2018). Blackwell et al.'s (2018) study did not find any influence of predator scent on the laying date of the first starling egg, clutch size, and hatchling number; these data were used in aspects of the current study.

\section{Index for Potentially Suitable Tree Cavities}

The constructed index for cavities parallels that of a habitat suitability index, which determines the overall suitability of habitat features for a focal species. Habitat suitability indices were not available for the starling or the Red-bellied Woodpecker (USFWS). Further, available resources limited the time and personnel necessary to search for and measure cavities during the starling breeding season, particularly considering obstruction by leaves. Instead, searches for excavated, natural, and limb-break cavities were conducted in the winter (January and February 2018). Cavity depth, and subsequently, volume, and evidence of nesting from the previous year (important factors for starling nest site selection; Mazgajski 2003) were not measured because of safety concerns associated with climbing dead or dying trees. Absent both cavity volume measurements and evidence of starling nesting, the constructed index was considered as a metric of a cavity's potential suitability for starling nesting.

The majority of trees at PBS are deciduous, and trees observed in January have completed their leaf drop (T. W. Seamans, pers. obs.). Tree cavities were located by 3 observers searching intensively within a $100 \mathrm{~m}$ radius plot, centered at randomly selected nest boxes $(\mathrm{n}=40$; Fig. 1$)$, selected from the 120 nest boxes used by Blackwell et al. (2018). Starlings tend to concentrate their activity within $100 \mathrm{~m}$ from a nest site, a distance which gradually decreases as the breeding season advances (Kessel 1957). Hence, starling occupants of tree cavities and nest boxes during the spring and summer of 2017 would likely have had knowledge of the surrounding availability of potential nesting cavities within this radius (Kessel 1957). It was assumed that no new cavities were formed, or no old cavities became unavailable, from the spring of 2017 into the winter of 2018 (approximately 6 months since the previous study was completed).

Cavity diameter is a critical component of suitability. Starlings physically cannot enter cavities that have an entrance less than $3.81 \mathrm{~cm}$ in diameter, and are part of a community of birds that use Northern Flicker (Colaptes auratus), Redheaded Woodpecker (Melanerpes erythrocephalus), and Red-bellied Woodpecker cavities_-which are all typically greater than $4.5 \mathrm{~cm}$ in diameter (Bent 1950; Peterson and Gauthier 1985; Ingold 1994). Starlings do not prefer the larger cavities $(10 \mathrm{~cm}$ in diameter) created by Pileated Woodpeckers (Dryocopus pileatus; Ingold 1994). Therefore, cavities were considered as potentially suitable for starling nesting if they were at least $4.5 \mathrm{~cm}$ in diameter and not a Pileated Woodpecker cavity, the latter of which are identifiable by their unique shape (Bull and Jackson 2011). Observers estimated the entrance size by comparing cavities to black wooden circles of known dimensions, suspended on elevated rods, held to the cavity (or as close to the cavity as possible). Also, the integrity of 


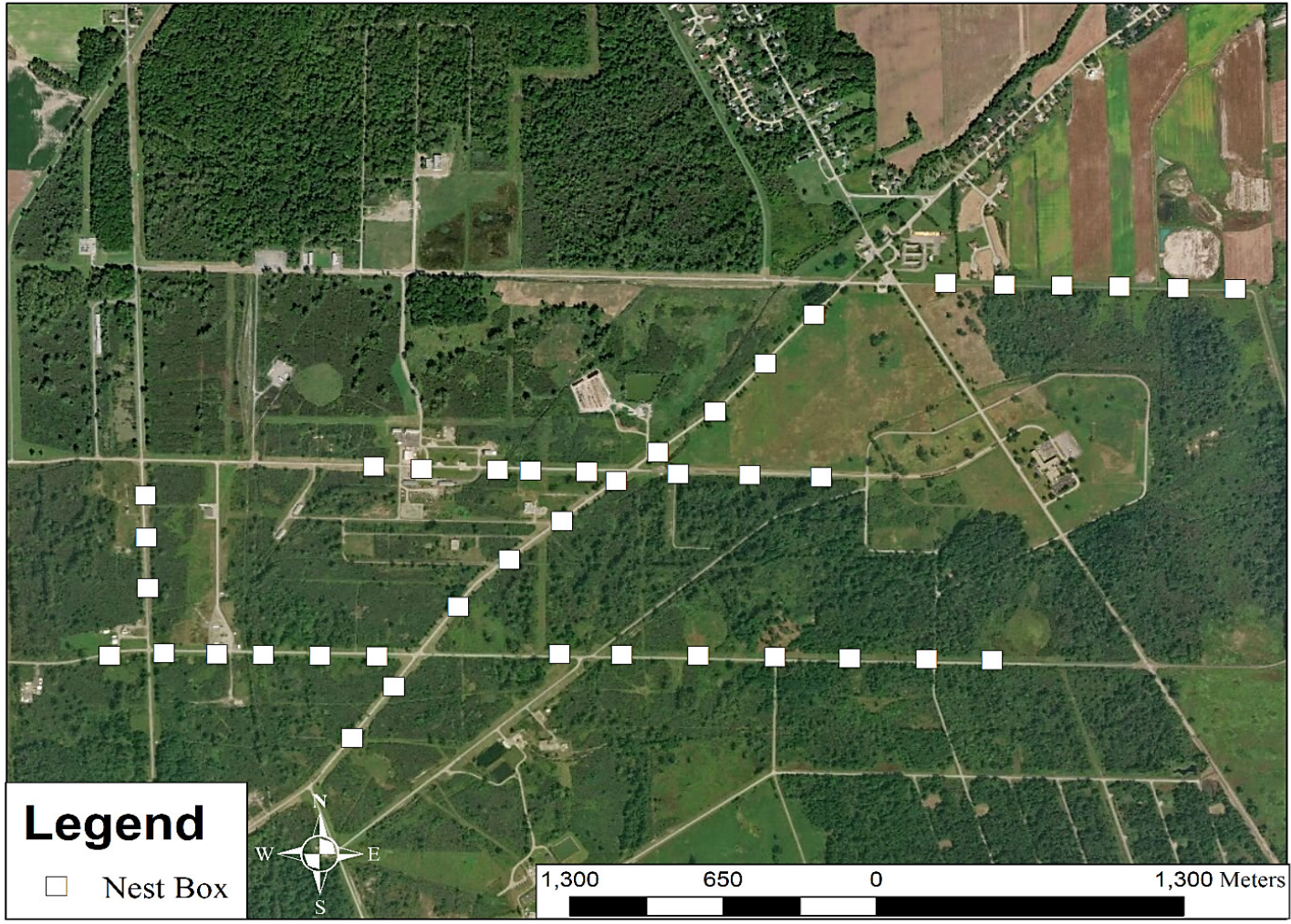

FIGURE 1. Location of nest boxes ( $n=40$, out of 120 total) where landscape features were measured at NASA's Plum Brook Station (PBS), Erie County, Ohio, United States

the cavity (i.e., completely enclosed or not) was scrutinized from the ground by at least 3 observers.

The observers also measured 8 variables at each tree hosting a potentially suitable cavity: tree status (i.e., dead, >3 limb-breaks equals major injuries, 1 or 2 limb-breaks equals minor injuries, or alive), if the cavity was made by a limb-break or a primary excavator, number of other potentially suitable cavities in the tree, diameter at breast height $(\mathrm{DBH})$, cavity height, canopy height, nearest entrance obstruction (i.e., nearest obstruction in front of each cavity entrance), and distance to dry grassland edge (Aitken and Martin 2004). The distance to dry grassland edge from the potential cavity was estimated using a range finder. However, if the vegetation was too dense, this measurement was calculated using the USGS GAP/LANDFIRE National Terrestrial Ecosystems 2011 dataset $\left(30 \mathrm{~m} \times 30 \mathrm{~m}\right.$ resolution) reclassified in ArcMap ${ }^{\circledR}$ 10.4 for Desktop (Esri ${ }^{\circledR}$, Redlands, California, United States). These 8 variables are known to be significant contributing factors in determining the potential suitability of tree cavities for starling nesting (Planck 1969; Peterson and Gauthier 1985; Carlson et al. 1998; Aitken and Martin 2004). Age of each cavity, volume, and presence of old nesting material are also important variables for starling occupancy (Mazgajski 2003; Mazgajski 2007). As noted above, observers could not access cavities to determine volume or inspect contents. Further, observers could not objectively determine cavity age over 1 survey season.

The potentially suitable cavity index comprised a value for each of the 8 variables (Table 1). As distance to dry grassland edge is considered an important factor for foraging, and not directly related to cavity parameters, this metric was weighted arbitrarily by a factor of 4 . Specifically, cavity preferences can differ regionally based on availability (pest invasion, excavator species, etc.), but grassland edges likely harbor preferred invertebrate prey regardless of geographical location (Aitken and Martin 2004; Heldbjerg et al. 2017).

Excavated and limb-breaks were the only categorical definitions for type of cavity. Starlings prefer cavities that have been freshly excavated to limb-break and natural cavities (Wesołowski 1989), therefore limb-break and natural cavities were assigned a value of " 1 " and excavated cavities a "2." Higher values for a variable corresponded with a desirable cavity characteristic. If a tree 
Table 1

Index for potentially suitable tree cavities for European Starlings (Sturnus vulgaris). Each cavity of the preferred diameter $(>4.5 \mathrm{~cm}$ and $<10 \mathrm{~cm})$ located within $100 \mathrm{~m}$ of a nest box was scored using this index. The total plot score involved the sum of the cavity scores for each plot. References refer to sources which suggest importance of the variable to starling nesting.

\begin{tabular}{|c|c|c|c|c|c|}
\hline \multirow[t]{2}{*}{ Variable } & \multirow[t]{2}{*}{ References } & \multicolumn{4}{|c|}{ Score } \\
\hline & & 0 & 1 & 2 & 3 \\
\hline $\begin{array}{l}\text { Distance to dry grassland } \\
\text { edge }(\mathrm{m})^{\text {a }}\end{array}$ & $\begin{array}{l}\text { Planck 1969; } \\
\text { Aitken and Martin 2004; } \\
\text { Heldbjerg et al. } 2017\end{array}$ & $>14$ & $11-13$ & $8-10$ & $<8$ \\
\hline Tree condition & Aitken and Martin 2004 & Dead & $\begin{array}{l}\text { Major } \\
\text { injuries }\end{array}$ & $\begin{array}{l}\text { Minor } \\
\text { injuries }\end{array}$ & Alive \\
\hline Canopy height of tree $(\mathrm{m})$ & $\begin{array}{l}\text { Planck 1969; } \\
\text { Peterson and Gauthier } 1985\end{array}$ & $<2.5$ & $2.6-5.0$ & $5.1-7.5$ & $>7.6$ \\
\hline Cavity height (m) & $\begin{array}{l}\text { Planck 1969; } \\
\text { Aitken and Martin } 2004\end{array}$ & $<0.4$ & $0.5-1.4$ & $1.5-2.4$ & $>2.5$ \\
\hline Number of other cavities & Aitken and Martin 2004 & $\geq 3$ & 2 & 1 & 0 \\
\hline $\mathrm{DBH}$ of nesting tree $(\mathrm{cm})$ & $\begin{array}{l}\text { Peterson and Gauthier 1985; } \\
\text { Aitken and Martin } 2004\end{array}$ & $<12$ & $13-23$ & $24-34$ & $>34$ \\
\hline Entrance obstruction (m) & Peterson and Gauthier 1985 & $<1$ & $1.1-2$ & $2.1-4.9$ & $>5$ \\
\hline Type of cavity & Wesołowski 1989 & --- & Limb-break & Excavated & --- \\
\hline
\end{tabular}

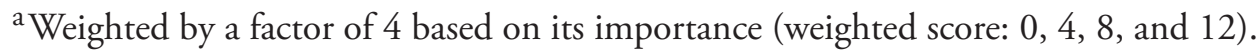

had more than 1 potentially suitable cavity, the type of cavity (limb-break or excavated) with the higher score was used. Although the starling is considered to be a semi-colonial nester, trees with multiple potentially suitable cavities might not score as well because of tree condition (Aitken and Martin 2004). Each potentially suitable cavity was scored using this index. Next, a total plot (i.e., the aforementioned $100 \mathrm{~m}$ radius around a selected nest box) score was calculated by adding all scores for a given plot. Greater total plot scores were assumed to be correlated with increased starling preference for tree cavities within the plot (i.e., the total plot score would be negatively correlated with the likelihood of starling occupancy of nest boxes).

\section{Landscape Variables}

The buildings in the study area were manually geo-referenced via ArcMap using Google ${ }^{\circledR}$ Earth $^{\text {тм }}$ imagery (Google Earth Pro 7.1.5). Starlings have been observed nesting in buildings at the study site since 1987 (T. W. Seamans, pers. obs.). A raster with pixel data $(30 \mathrm{~m} \times 30 \mathrm{~m}$ resolution) was created using the "raster" package in R (R Core Team 2018), and was used to determine the distance from the nearest building for each selected nest box. Each nest box was previously georeferenced ( $\pm 4 \mathrm{~m}$ accuracy) using a hand-held Garmin ${ }^{\circledR}$ GPSMAP ${ }^{\circledR}$ 64s (Garmin International Inc. Olathe, Kansas, United States). Because nest box location was uniformly distributed in a linear manor (every $60 \mathrm{~m}$ ) on utility poles, the search radius for other occupied starling nest boxes was increased to $200 \mathrm{~m}$. The number of other nest boxes falling within $200 \mathrm{~m}$ of a selected nest box in which starlings occupied (i.e., boxes containing $\geq 1$ egg, as recorded by Blackwell et al. 2018) was also calculated. Here, the "over" command in the "sp" package in $\mathrm{R}$ was used for all nest boxes ( $\mathrm{n}=120$; $\mathrm{R}$ Core Team 2018). The "over" command finds spatial objects (in this case, occupied starling nest boxes) within a certain area (here, a $200 \mathrm{~m}$ search radius). 


\section{Statistical Analysis}

Variables were checked for correlation, and those that were uncorrelated $(\mathrm{r}<0.8)$ were included in analyses (Freckleton 2011). These data were analyzed using a generalized linear model (GLM) with a binomial error term and a logistic link function to investigate the effects of the predictor variables on the probability of starling occupancy $(1=$ a nest box was occupied and starlings produced $\geq 1$ egg in $2017,0=a$ nest box was not active or used by another species). The full model (structured relative to the predictions) included number of neighboring occupied starling nest boxes, distance from buildings, and the total plot score as fixed effects. A model composed of distance from building as the sole fixed effect (because of the importance of mowed lawns kept around the buildings; Aitken and Martin 2004; Heldbjerg et al. 2017), as well as an intercept-only model, were also evaluated. No other variable combinations were evaluated. Models were compared using Akaike information criterion adjusted for small sample size (AICc; Burnham and Anderson 2002). Variable importance was evaluated by their $95 \%$ confidence intervals and if they overlapped zero. All statistical analyses were carried out using $\mathrm{R}$ software, version 3.4.4 (R Core Team 2018). We report means and standard errors of cavity measurements.

\section{RESULTS}

Between March and July 2017, starlings occupied $52 \%(\mathrm{n}=21)$ of 40 nest boxes randomly selected from Blackwell et al. (2018). The number of trees with potentially suitable cavities within $100 \mathrm{~m}$ plots around selected nest boxes ranged from 0 to 15 trees $(n=115$ trees, mean $=4$ trees per plot, SE \pm 0.75$)$. Woodpecker-excavated cavities predominate our sample ( $\mathrm{n}=171$ total cavities; excavated cavities: $\mathrm{n}=118$ or $69 \%$; natural limb-break cavities: $\mathrm{n}=53$ or $31 \%$ ). Excavated cavities were mainly observed in eastern cottonwoods (Populus deltoides), and limbbreak cavities were observed in maple trees (Acerspp.). Most cavities ( $\mathrm{n}=75,65 \%)$ were the only cavity in a tree (max cavities in a single tree $=5$ ). The largest DBH $(192 \mathrm{~cm})$ of a tree with a potentially suitable cavity was measured on an eastern cottonwood. The mean DBH of a tree with a potentially suitable cavity was $61 \mathrm{~cm}, S E \pm 2.6$. Maximum height of a tree with a potentially suitable cavity was $28 \mathrm{~m}$ (mean $=16 \mathrm{~m}$, $\mathrm{SE} \pm 0.85)$. Maximum height of a potentially suitable cavity was $27 \mathrm{~m}$ (mean $=8.5 \mathrm{~m}, \mathrm{SE} \pm 0.43)$. The mean distance between a potentially suitable cavity and the nearest obstruction was $4.1 \mathrm{~m}, \mathrm{SE} \pm 0.19$. Trees with potentially suitable cavities were composed of $20 \%$ live and $23 \%$ dead trees, and those with major $(31 \%)$ and minor $(26 \%)$ injuries. About $46 \%$ of trees with potentially suitable cavities were surrounded by or were within $29 \mathrm{~m}$ of grasslands (the smallest pixel size), 30\% of trees were located between 30 and $39 \mathrm{~m}$ away from grasslands, and the remaining $24 \%$ were over $40 \mathrm{~m}$ away from grasslands. Most nest boxes (58\%) did not have another occupied nest box within $200 \mathrm{~m}$. The mean distance from a building to a nest box was $330 \mathrm{~m}, \mathrm{SE} \pm 40$.

The 3 GLMs were all within $2 \triangle$ AICc, but the distance-from-building model had the highest model weight ( $\geq 2$ times that of other models) and a variable with a 95\% confidence interval that did not overlap zero (Table 2). In addition to low $\triangle \mathrm{AICc}$ for the full model, confidence intervals for the total plot score (CI: -0.01 to 0.01 ) and number of neighboring occupied starling nest boxes (CI: -2.16 to 0.21 ) overlapped zero; thus, these variables were considered superfluous. Nest boxes were more likely to be occupied when closer to buildings, a potential proxy for foraging areas in the form of mowed lawns (Fig. 2).

Table 2

Results from 3 generalized linear models predicting European Starling (Sturnus vulgaris) nest box occupancy at NASA's Plum Brook Station (PBS), Erie County, Ohio, United States

\begin{tabular}{llllll}
\hline \hline Model & Residual df & Residual deviance & AICc & $\Delta$ AICc & $\boldsymbol{W i}_{\mathbf{i}}$ \\
\hline Distance from building $^{\mathrm{a}}$ & 38 & 51 & 55 & 0 & 0.54 \\
$\begin{array}{l}\text { Distance from building + number of neighbors } \\
\text { + total plot scorec }\end{array}$ & 36 & 48 & 56 & 1.5 & 0.26 \\
\begin{tabular}{l} 
Intercept \\
\hline
\end{tabular} & 39 & 55 & 57 & 2 & 0.20 \\
\hline
\end{tabular}

${ }^{\mathrm{a}} 95 \%$ confidence interval $=-0.01$ to 0.00 . Confidence intervals from the full model are reported in the results.

${ }^{\mathrm{b}}$ Number of neighbors is the number of nest boxes occupied by European Starlings within $200 \mathrm{~m}$ of a given nest box.

${ }^{\mathrm{c}}$ Total plot score was calculated based on the index for potentially suitable tree cavities. 


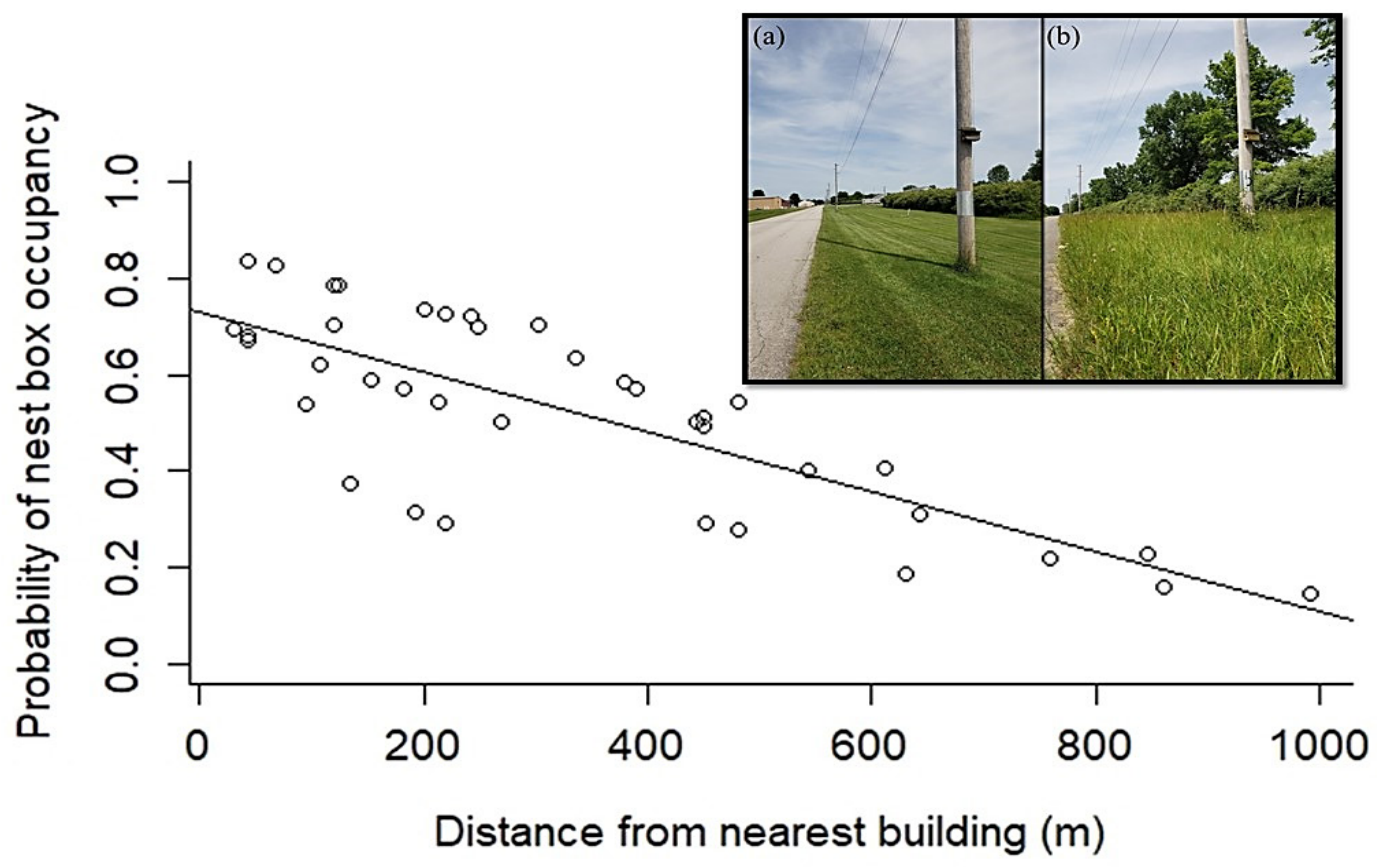

FIGURE 2. Probability of nest box occupancy for European Starlings (Sturnus vulgaris) in relation to distance from building at NASA's Plum Brook Station (PBS), Erie County, Ohio, United States. The fitted logistic equation from the generalized linear model is shown. The insert shows examples of grass height near nest boxes within (a) $100 \mathrm{~m}$ and (b) $300 \mathrm{~m}$ of a building. Photographs taken by M. B. Pfeiffer on June 15th, 2018, during the starling breeding season.

\section{DISCUSSION}

Contrary to the first 2 predictions, the potential cavity suitability index (via the total plot score) was not a significant predictor of the starlings' use of nest boxes. Starling occupancy of nest boxes was unaffected by the total plot score and nest box occupancy was not positively correlated with occupancy of neighboring nest boxes. Several possible, but non-mutually exclusive, factors may explain these findings: First, references used to calculate this index of potentially suitable cavities were not based on data from a United States eastern deciduous forest, but rather from conifer and aspen forests of Canada or from starlings' native range in Europe (Planck 1969; Peterson and Gauthier 1985; Carlson et al. 1998; Aitken and Martin 2004). Second, conflicting evidence for the importance of certain cavity characteristics-such as cavity height-was found (Planck 1969; Van Balen et al. 1982; Aitken and Martin 2004). For instance, a cavity suitability index would likely perform best if calibrated to local conditions, spatially and temporally to incorporate variance (e.g., abundance of nesting primary excavators, extent of invertebrate pest damage to wood, etc.; Stephens et al. 2015; Mouton and Martin 2018). Third, unlike the ecological data used to develop the index applied in this study, the landscape of this study site was fragmented and not in a continuous forest, which could have introduced an edge effect by increasing the chance of nest competition (Deng and Gao 2005). Fourth, observers were unable to make direct measurements of cavity volume. Finally, because surveys were conducted during the winter, the observers could not assess starling use and distance to other nesting starlings in cavities and/or buildings.

In support of the third prediction, it was observed that proximity to buildings was the most important predictor of starling nest box occupancy. It is likely that this variable was also an accurate predictor of short grass availability, because right-of-way areas beside roads were mowed more frequently when next to buildings on PBS property (M. B. Pfeiffer pers. obs.). Furthermore, there were likely other nesting starling pairs in the buildings, which would increase social information exchange about food resources and hence the preference for nesting location (Krause and Ruxton 2002). These findings are similar to results from Lerman et al. (2014) that found the percentage of landscape composed of buildings or maintained lawns was an important variable for starling habitat. Starlings likely preferred these short grass areas because the perceived risk of predation is lower (Devereux et al. 2005). 


\section{CONCLUSION}

Given that a relatively small percentage of the PBS property was searched (less than 6\%), but 171 potentially suitable cavities were detected, this study provides evidence that cavities for nesting starlings were not a scarce resource on PBS, as suspected by Seamans et al. (2015) and Blackwell et al. (2018). However,it was the proximity of buildings and their resources that influenced starling occupancy of nest boxes, not the availability of potentially suitable tree cavities. Future research examining starling use of nest boxes should consider nest box location in relation to buildings, particularly with regard to treatments intended to deter nesting.

\section{ACKNOWLEDGMENTS}

Research was supported by the U. S. Department of Agriculture, Animal and Plant Health Inspection Service, Wildlife Services, National Wildlife Research Center. T. L. DeVault, R. B. Iglay, M. S. DrabikHamshare, and 6 anonymous reviewers provided constructive comments on earlier drafts of the manuscript.

\section{LITERATURE CITED}

Aitken KEH, Martin K. 2004. Nest cavity availability and selection in aspen conifer groves in a grassland landscape. Can J Forest Res. 34(10):2099-2109. https://doi.org/10.1139/x04-086

Aitken KEH, Martin K. 2008. Resource selection plasticity and community responses to experimental reduction of a critical resource. Ecology. 89(4):971-980.

https://doi.org/10.1890/07-0711.1

Belant JL, Woronecki PP, Dolbeer RA, Seamans TW. 1998. Ineffectiveness of five commercial deterrents for nesting starlings. Wildlife Soc B. 26(2):264-268. https://www.jstor.org/stable/3784047

Bent AC. 1950. Life histories of North American wagtails, shrikes, vireos, and their allies: order Passeriformes. Washington (DC): Smithsonian Institution, United States National Museum. 411 p. Bulletin 197: pp 182. https://doi.org/10.5479/si.03629236.197.1

Blackwell BF, Seamans TW, Pfeiffer MB, Buckingham BN. 2018. European Starlings (Sturnus vulgaris) reproduction undeterred by predator scent inside nest boxes. Can J Zool. 96(9):980-986.

https://doi.org/10.1139/cjz-2017-0299

Bowles MD, Arrighi RS. 2004. NASA's nuclear frontier: the Plum Brook Reactor Facility. Washington (DC): National Aeronautics and Space Administration(US), History Division. 187 p. Monographs in Aerospace History Series, No. 33; NASA SP: 2004-4533.

https://history.nasa.gov/SP-4533/sp4533.htm
Bridgman CJ. 1962. Birds nesting in aircraft. Brit Birds. 55(11):461-470. https://britishbirds.co.uk/article/birds-nesting-in-aircraft/

Bull EL, Jackson JA. 2011. Pileated Woodpecker (Dryocopus pileatus). Ver. 2.0. In: Poole AF, editor. The birds of North America. Ithaca (NY): Cornell Lab of Ornithology. https://doi.org/10.2173/bna.148

Burnham KP, Anderson DR. 2002. Model selection and multimodel inference: a practical information-theoretic approach. 2nd ed. New York (NY): Springer-Verlag. 488 p. ISBN13: 978-0387953649

Caccamise DF, Morrison DW. 1986. Avian communal roosting: implications of diurnal activity centers. Am Nat. 128(2):191-198. https://doi.org/10.1086/284553

Campbell S, Powell C, Parr R, Rose K, Martin G, Woolnough A. 2012. Can artificial nest-cavities be used as a management tool to assist the control of Common Starlings (Sturnus vulgaris)? Emu. 112(3):255-260. https://doi.org/10.1071/MU11050

Carlson A, Sandström U, Olsson K. 1998. Availability and use of natural tree holes by cavity nesting birds in a Swedish deciduous forest. Ardea. 86(1):109-119.

http://urn.kb.se/resolve?urn=urn:nbn:se:oru:diva-3138

Chapman FM. 1925. The European Starling as an American citizen. Nat Hist. 25(4):480-485.

Deng WH, Gao W. 2005. Edge effects on nesting success of cavity-nesting birds in fragmented forests. Biol Conserv. 126(3):363-370. https://doi.org/10.1016/j.biocon.2005.06.013

DeVault TL, Belant JL, Blackwell BF, Seamans TW. 2011. Interspecific variation in wildlife hazards to aircraft: implications for airport wildlife management. Wildlife Soc B. 35(4):394-402. https://doi.org/10.1002/wsb.75

Devereux CL, Whittingham MJ, Fernández-Juricic E, Vickery JA, Krebs JR. 2005. Predator detection and avoidance by starlings under differing scenarios of predation risk. Behav Ecol. 17(2):303-309. https://doi.org/10.1093/beheco/arj032

Dolbeer RA, Link MA, Woronecki PP. 1988. Naphthalene shows no repellency for starlings. Wildlife Soc B. 16(1):62-64. www.jstor.org/stable/3782355.

Feare C. 1984. The starling. Oxford; New York (NY): Oxford University Press. 315 p. ISBN13: 978-0192177056. https://archive.org/details/starling00fear

Freckleton RP. 2011. Dealing with collinearity in behavioural and ecological data: model averaging and the problems of measurement error. Behav Ecol Sociobiol. 65(1):91-101. https://doi.org/10.1007/s00265-010-1045-6

Heldbjerg H, Fox AD, Thellesen PV, Dalby L, Sunde P. 2017. Common Starlings (Sturnus vulgaris) increasingly select for grazed areas with increasing distance-to-nest. PLoS ONE. 12(8):e0182504. https://doi.org/10.1371/journal.pone.0182504 
Ingold DJ. 1989. Nesting phenology and competition for nest sites among Red-headed and Red-bellied Woodpeckers and European Starlings. Auk. 106(2):209-217.

Ingold DJ. 1994. Influence of nest-site competition between European Starlings and woodpeckers. Wilson Bull. 106(2):227-241. www.jstor.org/stable/4163416

Ingold DJ. 1998. The influence of starlings on flicker reproduction when both naturally excavated cavities and artificial nest boxes are available. Wilson Bull. 110(2):218-225.

www.jstor.org/stable/4163931

Jackson J. 2000. Rapid nest-site selection and initiation of nests on commercial aircraft by European Starlings. Migrant. 71(4):97-99.

Kerpez TA, Smith NS. 1990. Competition between European Starlings and native woodpeckers for nest cavities in saguaros. Auk. 107(2):367-375.

https://doi.org/10.2307/4087621

Kessel B. 1957. A study of the breeding biology of the European Starling (Sturnus vulgaris L.) in North America. Am Midl Nat. 58(2):257-331. https://doi.org/10.2307/2422615

Koenig WD. 2003. European Starlings and their effect on native cavity-nesting birds. Conserv Biol. 17(4):1134-1140. https://doi.org/10.1046/j.1523-1739.2003.02262.x

Koenig WD, Liebhold AM, Bonter DN, Hochachka WM, Dickinson JL. 2013. Effects of the emerald ash borer invasion on four species of birds. Biol Invasions. 15(9):2095-2103. https://doi.org/10.1007/s10530-013-0435-x

Koenig WD, Walters EL, Rodewald PG. 2017. Testing alternative hypotheses for the cause of population declines: The case of the Red-headed Woodpecker. Condor. 119(1):143-154. https://doi.org/10.1650/CONDOR-16-101.1

Krause J, Ruxton GD. 2002. Living in groups. Oxford; New York (NY): Oxford University Press. 210 p. ISBN13: 9780198508182.

Lerman SB, Nislow KH, Nowak DJ, DeStefano S, King DI, Jones-Farrand DT. 2014. Using urban forest assessment tools to model bird habitat potential. Landscape Urban Plan. 122(1):29-40.

https://doi.org/10.1016/j.landurbplan.2013.10.006

Linz GM, Avery ML, Dolbeer RA, editors. 2017. Ecology and management of Blackbirds (Icteridae) in North America. Boca Raton (FL): CRC Press. 252 p. ISBN13: 978-1498799614. https://doi.org/10.4324/9781315156439

Martin K, Aitken KEH, Wiebe KL. 2004. Nest sites and nest webs for cavity-nesting communities in interior British Columbia, Canada: nest characteristics and niche partitioning. Condor. 106(1):5-19.

https://doi.org/10.1093/condor/106.1.5

Marzluff JM, Bowman R, Donnelly R, editors. 2001. Avian ecology and conservation in an urbanizing world. Boston (MA): Springer. 585 p. ISBN13: 978-0792374589.

https://doi.org/10.1007/978-1-4615-1531-9

Mazgajski TD. 2000. Competition for nest sites between the starling Sturnus vulgaris and other cavity nesters-study in forest park. Acta Ornithol. 35(1):103-107.
Mazgajski TD. 2003. Nest site choice in relation to the presence of old nests and cavity depth in the starling Sturnus vulgaris. Ethol Ecol Evol. 15(3):273-281.

https://doi.org/10.1080/08927014.2003.9522672

Mazgajski TD. 2007. Effect of old nest material in nestboxes on ectoparasite abundance and reproductive output in the European Starling (Sturnus vulgaris L.). Pol J Ecol. 55(2):377385.

McClure CJW, Hilleary DM, Spurling DP. 2015. American Kestrels actively exclude European Starlings from using a nest box. J Raptor Res. 49(2):231-233.

https://doi.org/10.3356/0892-1016-49.2.231

McGilvrey FB, Uhler FM. 1971. A starling-deterrent wood duck nest box. J Wildlife Manage. 35(4):793-797.

https://doi.org/10.2307/3799789

Mennechez G, Clergeau P. 2006. Effect of urbanisation on habitat generalists: starlings not so flexible? Acta Oecol. 30(2):182-191.

https://doi.org/10.1016/j.actao.2006.03.002

Mouton JC, Martin TE. 2018. Fitness consequences of interspecific nesting associations among cavity-nesting birds. Am Nat. 192(3):389-396. https://doi.org/10.1086/698873

Newton I. 1994. The role of nest sites in limiting the numbers of hole-nesting birds: a review. Biol Conserv. 70(3):265-276. https://doi.org/10.1016/0006-3207(94)90172-4

[ODNR] Ohio Department of Natural Resources, Division of Forestry. 2019. Insects \& Diseases. [accessed 2019 Mar 13]. http://forestry.ohiodnr.gov/pests

Pardieck KL, Ziolkowski DJ Jr, Lutmerding M, Hudson MAR. 2018. North American Breeding Bird Survey Dataset 19662017. U. S. Geological Survey, Patuxent Wildlife Research Center. http://www.pwrc.usgs.gov/bbs

Pérez JH. 1988. Estornino pinto el la capital federal. Nuestra Aves. 17(1):14.

Peterson B, Gauthier G. 1985. Nest site use by cavity-nesting birds of the Cariboo Parkland, British Columbia. Wilson Bull. 97(3):319-331.

https://www.jstor.org/stable/4162105

Pimentel D, Lach L, Zuniga R, Morrison D. 2000. Environmental and economic costs of nonindigenous species in the United States. Bioscience. 50(1):53-65. https://doi.org/10.1641/0006-3568(2000)050[0053:EAE $\mathrm{CON}] 2.3 . \mathrm{CO} ; 2$

Planck RJ. 1969. Nest site selection and nesting of the European Starling (Sturnus vulgaris L.) in California [PhD thesis]. [Davis (CA)]: Department of Zoology, University of California, Davis.

R Core Team. 2018. R: A language and environment for statistical computing. Vienna (Austria): R Foundation for Statistical Computing. https://www.r-project.org/

Seamans TW, Blackwell BF, Tyson LA. 2015. Low occupancy rates of artificial nest cavities by European Starlings. Ohio J Sci. 115(2):53-55. https://doi.org/10.18061/ojs.v115i2.4943 
Stephens PA, Pettorelli N, Barlow J, Whittingham MJ, Cadotte MW. 2015. Management by proxy? The use of indices in applied ecology. J Appl Ecol. 52(1):1-6. https://doi.org/10.1111/1365-2664.12383

Tyson LA, Blackwell BF, Seamans TW. 2011. Artificial nest cavity used successfully by native species and avoided by European Starlings. Wilson J Ornithol. 123(4):827-830. https://doi.org/10.1676/11-003.1

[USFWS] U.S. Fish and Wildlife Service. [date unknown]. Habitat Suitability Index [individual reports unknown]. U.S. Fish and Wildlife Service. Series title: FWS/OBS. Series No.: 82 [individual reports unknown]. Subseries: Habitat Suitability Index. [accessed 2019 Mar 14]. Available from: United States Geological Survey, Publication Warehouse. https://pubs.er.usgs.gov/search?q=FWS\%2FOBS+82

Van Balen JH, Booy CJH, Van Franeker JA, Osieck ER. 1982. Studies on hole-nesting birds in natural nest sites. Ardea. 55(1-2):1-24.

https://doi.org/10.5253/arde.v70.p1
Wesołowski T. 1989. Nest-sites of hold-nesters in a primaeval temperate forest (Bialowieża National Park, Poland). Acta Ornithol. 25(3):321-351.

Wesołowski T. 2017. Failed predator attacks: a direct test of security of tree cavities used by nesting Marsh Tits (Poecile palustris). Auk. 134(4):802-810. https://doi.org/10.1642/AUK-17-51.1

Winterbottom JM, Liversidge R. 1954. The European Starling in the south west Cape. Ostrich. 25(2):89-96. https://doi.org/10.1080/00306525.1954.9633410

Zufiaurre E, Abba A, Bilenca D, Codesido M. 2016. Role of landscape elements on recent distributional expansion of European Starlings (Sturnus vulgaris) in agroecosystems of the Pampas, Argentina. Wilson J Ornithol. 128(2):306-313. https://doi.org/10.1676/wils-128-02-306-313.1 